\title{
THE STUDY OF THE ORE BODIES ZONALITY BY COMPOSITION OF OLIVINE IN THE CHROMITE DEPOSIT NO. 219 OF THE VERKH- NEYVINSKY MASSIF (MIDDLE URALS)
}

A. V. Alekseev

\section{ИЗУЧЕНИЕ ЗОНАИЬНОСТИ РУАНЫХ ТЕА ПО СОСТАВУ ОЛИВИНА В ХРОМИТОВОМ МЕСТОРОЖАЕНИИ № 219 ВЕРХ-НЕЙВИНСКОГО МАССИВА (СРЕАНИЙ УРАИ)}

А. В. Аиексеев

Рассмотрена хромитоносная рудная зона на месторождении № 217 южной части Верх-Нейвинского массива, сложенная дунитами с вкрапленными хромитовыми рудами. Рудная зона имеет вылержанную мощность около 50 м, меридиональное простирание и пацение $35^{\circ}$. Хромитовые руды характеризуются четко выраженной полосчатостью, элементы залегания которой в точности повторяют элементы залегания рудной зоны в целом. Под рудной зоной залегает блок цунитов с прожилково-вкрапленными хромитовыми рудами. В целом рудная зона рассматривается нами как типичное позднемагматическое месторожцение. Повышенные концентрации хромшпинелида формируют рудные тела, пригодные мля промышленной отработки.

Изучалось изменение химического состава хромшпинелима и оливина вкрест простирания рудной зоне. Хромшпинелил по составу высокохромистый, слабо метаморфизованный, имеет выцержанный состав по всей рудной зоне. По железистости оливина наблюдается четко выраженная зональность от максимальных значений на краях зоны (7-8 \% Fa) до минимальных в центре (3-4 \% Fа). Подобная зональность на уральских месторождениях хромитовых руд выявлена впервые. По нашему мнению, причина появления такой зонаиьности закиючается в первичном перераспределении вешества при кристамизации хромититов из остаточного расплава.

Также в изученных образцах повсеместно наблюдается многократно описанное явление посткристамизационного перераспределения железа между сосушествуюшими зернами оливина и хромшпинелида. Как и в Аругих описанных в ^итературе случаях, перераспределение наблюдается в узкой контактовой зоне обоих минералов.

Киючевые слова: Верх-Нейвинский массив; хромитовые руды; хромшпинелиц; оливин; зональность; рудоносная зона.

The author considers chromite-bearing ore zone at deposit No. 217 of the southern part of the Verkh-Neyvinsky massif composed of dunites with disseminated chromite ores. The ore zone has a sustained thickness of about 50 meters, a meridional strike and a dip of $35^{\circ}$. Chromite ores are characterized by the clearly defined banding, the elements of occurrence of which exactly repeat the elements of occurrence of the ore zone as a whole. Under the ore zone, there is a block of dunites with vein-disseminated chromite ores. In general, we consider the ore zone as a typical late-magmatic deposit. Increased concentrations of chromospinelide form the ore bodies that are suitable for industrial processing.

The study covers a change in the chemical composition of chromospinelide and olivine along the strike of the ore zone. Chromospinelide has a high chromium com position, slightly metamorphosed, and its composition is consistent throughout the entire ore zone. The iron content of olivine shows a clearly defined zonality from the maximum values at the edges of the zone $(7-8 \% \mathrm{Fa})$ to the minimum values at the center (3-4\% Fa). This is the first occurrence of corresponding zonality in the Ural deposits of chromite ores. In our opinion, the reason for the appearance of such zonality is in the primary redistribution of matter during the crystallization of chromites from the residual melt.

In addition, in the studied samples, one can observe the repeatedly described phenomenon of post-crystallization redistribution of iron between the coexisting grains of olivine and chromospinelide. As in other cases described in the literature, redistribution happens in the narrow contact zone of both minerals.

Keywords: The Verkh-Neyvinsky massif; chromite ores; chromospinelide; olivine; zonality; ore zone.

A brief description of the massif and chromites

The Verkh-Neyvinsky massif is one of the least studied chromite-bearing massifs in the Middle Urals. At the same time, the chromite industry of Russia "originated" on it. Here were the very first chromite mines in the Urals (1880s), the remains of which one can still observe today.

The massif has a complex geological structure. It has a dropshaped form, ranging from $10 \mathrm{~km}$ wide in the north to $1-2$ in the south, containing the rocks of the Sjuzel, Kirovgrad and Kungurk suites, the contacts of the massif with them are tectonic with a dip to the east at angles of $55-80^{\circ}$. The northern part of the massif is mainly composed of dunites, which contact in the north and east with a gabbroid massif. Along the contact develops a thick zone of clinopyroxenites with subdued verlites and olivine clinopyroxenites. The southern part of the massif is also represented by an extended dunite body, clamped between the clinopyroxenite and the bandings. According to geophysical data, the ultrabasites form a layer-like deposit underlain by gabbroids, the vertical thickness of which reaches $5 \mathrm{~km}$.

A lot of chromite deposits have been identified (and for the most part worked out) on the massif, some of them are single bodies chaotically scattered along the massif, but the bulk of them concentrates in two ore fields. The northern field is the Leshachie ravines (26 chromite displays and deposits), represented by numerous lenticular bodies of solid, less often disseminated ores, and usually worked to a depth of up to $60 \mathrm{~m}$. The distribution of deposits is chaotic, with no apparent reference to any geological structures. The southern field is the Sharomsky Mountains (10-12 objects), represented by lenticular and tabular deposits with a predominance of disseminated mineralization.

Both ore fields have similarities in geological structure. They are confined to the marginal dunite-clinopyroxenite complex (DC), ore bodies occur in dunite blocks, by composition chromites have high chromium content, metallurgical varieties, and are generally susceptible to weakly expressed processes of secondary changes. The Sharomsky field is much smaller (dunite block area is smaller) than Leshachie, so the chromite bodies are smaller, and disseminated ores predominate.

The material for this study

During several years of work, we accumulated a rather large amount of stone material for the chromite deposits of the massif. In the northern group of deposits (Leshachie ravines), we mostly studied abandoned quarries, the remains of ore bodies were rare, most of the material was from dumps or remaining uncovered walls. In the southern group (Zhuzhinsky Mountains), we conducted active prospecting and mining operations for several years, so the accumulated material is highly representative and mainly includes core samples for ores and enclosing rocks.

Overall, a study covers material from 15 wells crossing ore bodies. Of these, a large part (7 wells) is for deposit No. 219.

Objectives. The main objective of this research was to study the structure of chromite bodies with the search for an explicit or hidden zonality in composition. To this end, we studied structures and textures of ores, contacts with host rocks, and selected series of ore samples intersecting ore bodies for successive production of polishes and thin sections with their description. 


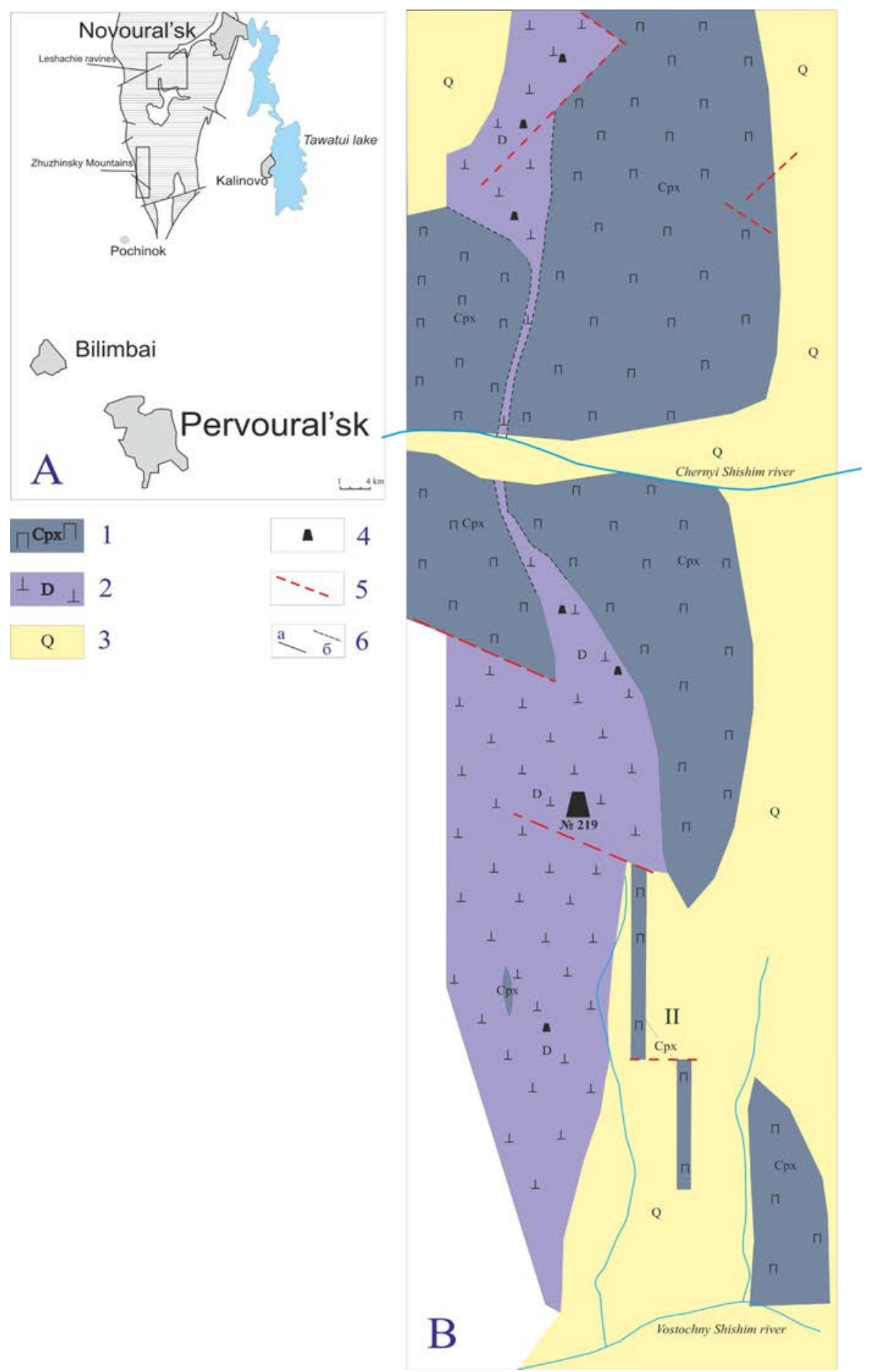

Figure 1. Schematic map of the Verkh-Neyvinsky Massif (A) and the section Zhuzhinsky Mountains (B). 1 - clinopyroxenites with subordinate bodies of verlites; 2 - dunites and apodunite serpentinites; 3 - valleys of rivers and streams, covered with a mantle of quaternary sediments; 4 - old and current chromite ore quarries; 5 - tectonic contacts; 6 - assumed tectonic boundaries.

For the most thoroughly studied (drilled by a dense network of wells) deposit No. 219, we obtained a large volume of microprobe analyzes for coexisting olivine and chromospinelide in order to search for the internal zoning of chromite bodies in terms of the composition of the minerals.

Previous studies on this topic

The first consideration of the search for hidden zonality in chromite bodies appeared in the works of Tsaritsyn [8], who showed a change in chromicity in the ore bodies of the Kempirsaysky massif from the center to the edge of the deposit. Later, zonality in chromite bodies by the composition of the ore chromospinelide was covered by various examples in the works of Ukhanov [7], Chashchukhin [9] Alekseev [1], et al. In general, all researchers note a pronounced zonality, consisting in the chromicity increase of the ore chromospinelide from the edge of the ore body to its center. In addition, there is a general increase in the chromium content of the mineral as the density of dissemination of ores increases.

The structure of the studied deposit

Earlier we already considered in detail the structure of the ore-bearing zone of deposit No. 219 [2]. We showed that the ore-bearing zone is a layered body with clearly delineated boundaries. The host rocks are represented by serpentinized dunites with a ferrugi- 

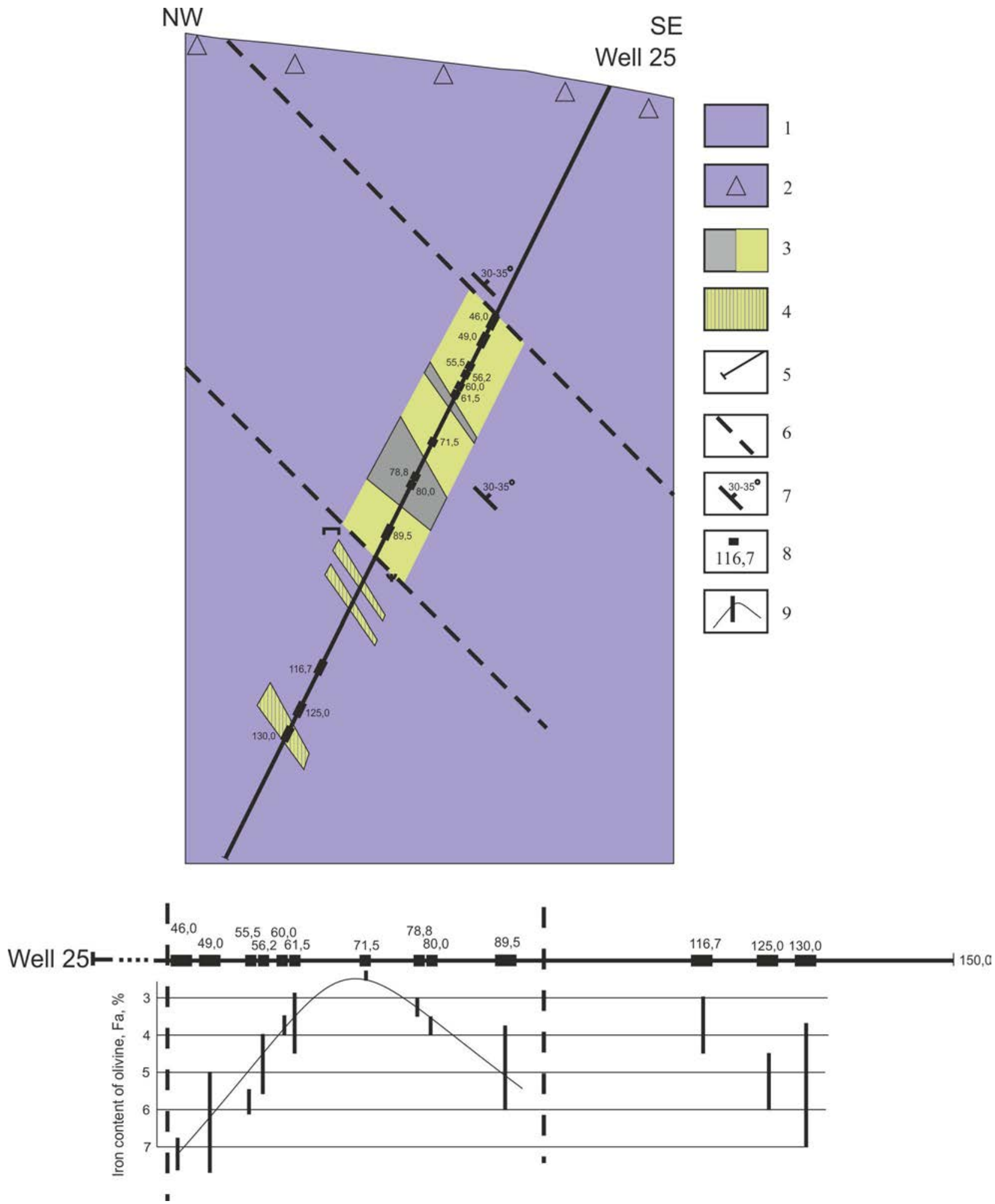

Figure 2. Geological section along the ore zone of deposit No. 219 and change in the composition of olivine along well No. 25. 1 - apodunite serpentinites and serpentinized dunites; 2 - weakly serpentinized dunites; 3 - ore bodies separated by contouring data (border $15 \% \mathrm{Cr}_{2} \mathrm{O}_{3}$ ); $4-\mathrm{zone}_{\mathrm{O}}$ of weathering and soil-vegetation layer; 5 - exploratory wells; 6 - boundaries of the ore zone; 7 - elements of the banding of ores; 8 - elements of occurrence of the ore zone; 9 - sampling points along the well (a) and the range of variation in the iron content of the olivines measured in them (b).

nous content of 7-8 \%. The ore zone has a reduced iron content of ore-bearing dunites (3-5\%) and a characteristic light color (clarified dunites). Below the ore zone, there is a zone of vein mineralization in the form of thin (up to the few meters) veins of clarified serpentinites with chromite mineralization.

The chromites in the ore zone are characterized by banded textures; the elements of occurrence of banding always correspond to the elements of occurrence of the zone as a whole. The distribution of chromospinelide within the zone is rather chaotic. The results of contouring along the side content distinguish the ore bodies; they have a lenticular shape, the strike as a whole coincides with the strike of the zone.

After the extraction of the ore zone of deposit No. 219, we attempted to find some zonality in the composition of the minerals within it. Since the only primary minerals are olivine and chromo- 
a

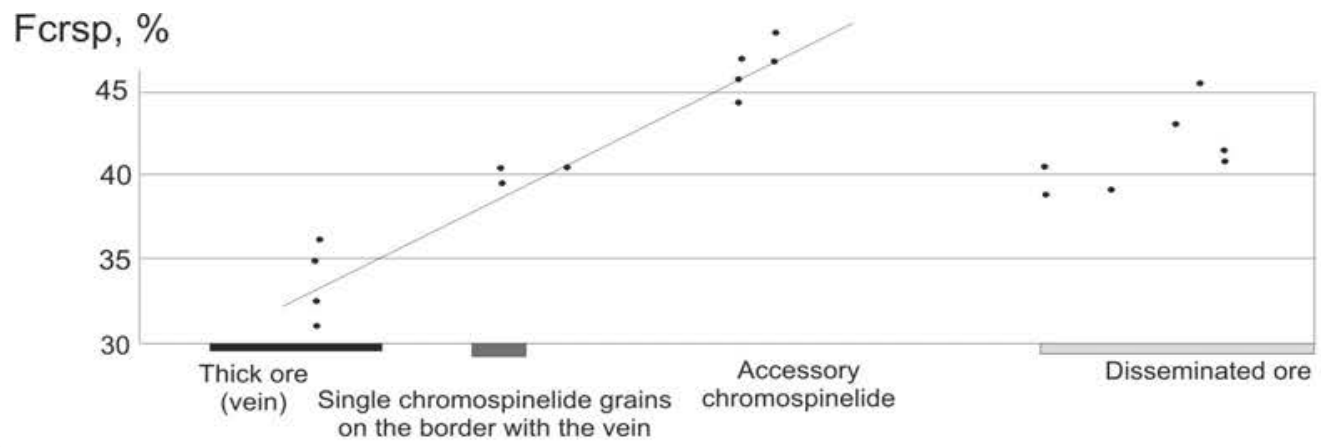

Fol

$\mathrm{Fa}, \%$

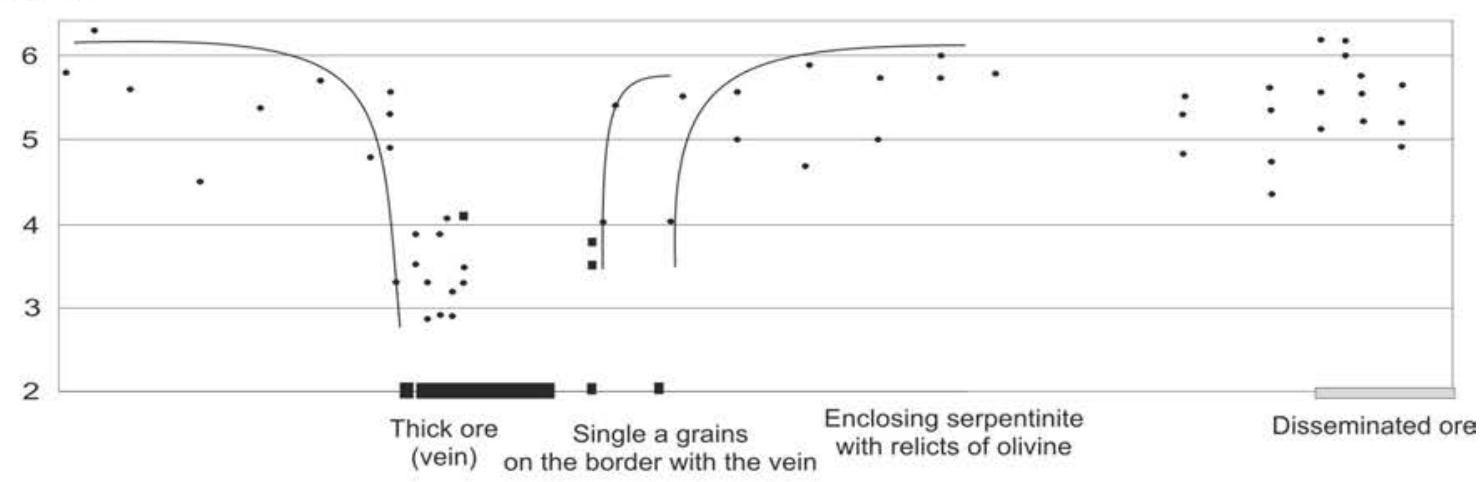

$b$

Fol

$\mathrm{Fa}, \%$

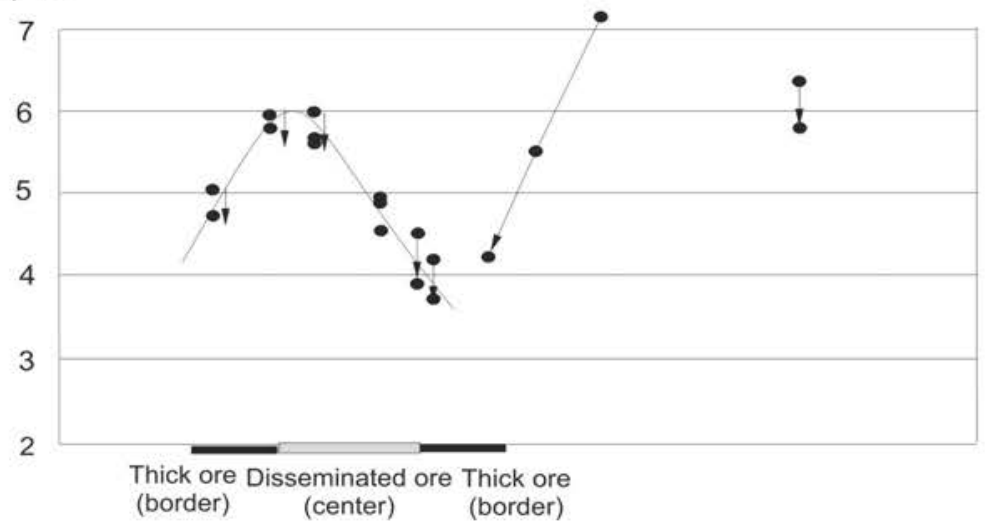

Fol

$\mathrm{Fa}, \% \quad \mathrm{BH} 24 / 44,5$ - section with accessory grains

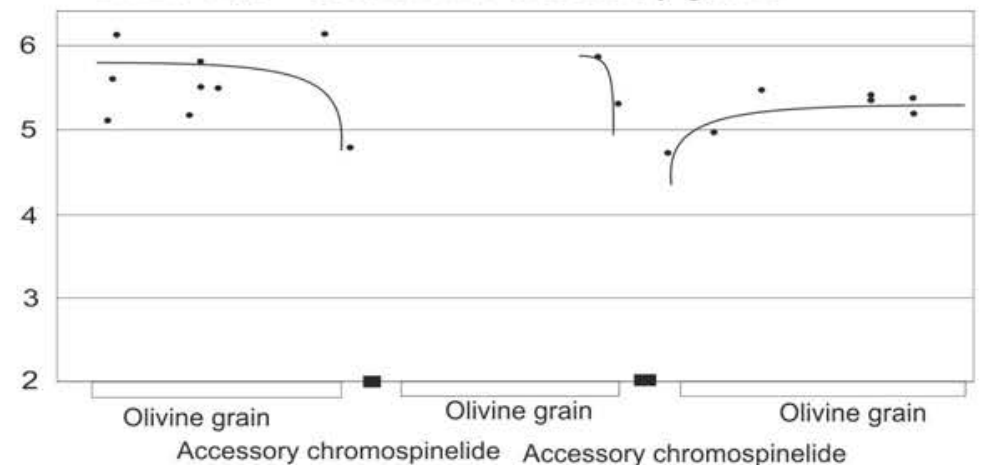

Figure 3. Change in the ferruginousness of coexisting olivine and chromospinelide by microsections of samples No. $23 / 50.5$ (a), $25 / 130.0$ (b) and $24 / 44.5$ (c). Note. The arrows show changes in the iron content of olivine from the center of the grain to the edge. The lines show the trend of the olivine compositions changes as it approaches the grain of chromospinelide.

Alekseev A. V. The study of the ore bodies zonality by composition of olivine in the chromite deposit No. 219 of the Verkh-Neyvinsky 37 massif (Middle Urals) // Известия УГГУ. 2017. Вып. 3(47). С. 34-38. DOI 10.21440/2307-2091-2016-3-34-38 
spinelide, they were a focus of the study. In Fig. 2, one can see the most representative section of the ore zone. Of the samples from all the wells, the number of samples and the data obtained from well No. 25 turned out to be the largest and most successful for analysis.

Description of chromites. Incipient and banded textures predominate in ores with an ore mineral content ranging from 5-10 to $20-25 \%$. The shape of the chromospinelide grains is distinctly idiomorphic (octahedral), splices or irregular forms of selections are much less common. The grain size of chromospinelide varies from $0.2-0.3 \mathrm{~mm}$ to 1 $\mathrm{mm}$. Herewith, generally, there is no predominant grain size for each sample. Usually there are large grains surrounded by a scattering of smaller ones. The dependence of the grain size on the density of impregnation exists (in dense and massive ores the grain size is larger than in the poor ones), but it is very weak.

Virtually all ores are more or less susceptible to secondary processes of substitution of chromospinelide by magnetite. Microscopically it appears in the form of development of the clarified (chromium-magnetite) sections along the primary chromospinelide. The amount of chromagnetite varies from 3-5 to $20 \%$, in poor ores it is higher than in rich ones. Incidentally, there is one significant difference in the pattern of the changes in chromospinelide in comparison with the ores of other massifs. Chromagnetite is distributed over the grains in the form of irregularly shaped spots without a clear confinement to grain boundaries or cracks. The reason for such a chaotic replacement of chromospinelide is still unclear.

The primary (unaffected) chromospinelide is characterized by a rare consistency of the composition throughout the span of the ore zone. The fluctuations in the contents of the main components are very insignificant. There was no detected change in the composition of the ore chromospinelide across the ore zone. Instead, one can see the repeatedly described [7] dependence of the content of basic elements in chromospinelide from the density of dissemination: as the density of dissemination of ores increases in chromospinelide, the proportion of chromium increases due to a proportional decrease in the content of magnesium and aluminum. The example of a microsection along one of the samples clearly shows it (Fig. 3, a).

Characteristics of olivine. Olivine in the ore is partially serpentinized (from 50 to $80 \%$ ), but one can find fresh relics in all samples. Olivine grains are round, with a size of $0.5-0.6 \mathrm{~mm}$. Olivine is characterized by a thin primary dissemination of early magnetite [9].

On the graph of the change in the iron content of olivine across the ore zone (see Fig. 2) appears a rather beautiful curve of its gradual decrease from the boundaries of the zone to its center. However, when going to the lower level, the analysis of the change in the ferruginousness of olivine within a single sample elucidates other regularities (Fig. 3).

Fig. 3 shows some of the most informative microsections of 2-3 $\mathrm{cm}$ length by samples of ores $(a, b)$ and rocks $(c)$ with measurements of olivine and chromospinelide compositions at different points. Distorted horizontal scale in the drawings is for convenience of presentation.

It is clear that the iron content of olivine is fairly well sustained in the range of 5-6\% and sharply decreases on contact with the grain of chrome spinel to $3-4 \%$, i.e. redistribution of components between minerals is carried out mainly in a narrow contact part with the width of the first parts of mm. Different papers [3] repeatedly described earlier this phenomenon was. If we consider olivine inclusions in chromospinelide, the picture is similar, and the width of the zone with iron redistribution remains unchanged. In relatively coarse grains-inclusions, the central part has a ferruginous content at the level of the same 5-6 \% Fa, and a decrease occurs at the contact with the chro- mospinelide-bearer. Small grains (up to $0.2-0.3 \mathrm{~mm}$ ) have a low iron content of 3-4 Fa over the entire area. The same applies to the reverse picture - the contact of the accessory grain of chromospinelide and a large grain of olivine (Fig. 3, c). Redistribution of elements between coexisting grains goes in a narrow contact part.

After reconsidering the distribution of iron content of olivine over the ore-bearing zone as a whole, according to this data, the primary curve of the change in the iron content of olivine in Fig. 2 somewhat smoothens, since in sample No. 71.5 we analyzed only olivine inclusions with minimal iron content. Nevertheless, its general form remains.

Conclusions

The ore-bearing zone of deposit No. 219 has a pronounced zonation by the change in the iron content of olivine from 7-8 \% Fa at its boundaries to $3-4 \% \mathrm{Fa}$ in the center. The studied samples widely display already known phenomenon of post-crystallization redistribution of iron between coexisting grains of olivine and chromospinelide. We emphasize that it occurs only in a narrow contact zone of both minerals.

The reason for the appearance of such zonality in the composition of olivine is still unclear. Probably, this is a reflection of processes during the formation of the ore zone - crystallization of the residual melt.

The research was carried out with the support of research work No. 1201257647 "Geochemical factors of the origin and evolution of endogenous ore-forming systems of folded regions".

\section{REFERENCES}

1. Alekseev A. V. 2006, Zonal'nost' rudnykh tel po sostavu khromshpinelidov [Zone of ore bodies in composition of chromospinelides]. 8-e Chteniya imeni Chirvinskogo [8th Chirvinsky Readings], Perm'.

2. Alekseev A. V., Chernetskaya M. V. 2011, Stroenie khromitovykh rudnykh zon v dunitakh al'pinotipnykh massivov [The structure of chromite ore zones in dunites of alpinotypic massifs]. Metallogeniya drevnikh i sovremennykh okeanov [Metallogeny of ancient and modern oceans], Miass, p. 72--75.

3. Varlakov A. S. 1996, Dunit-verlit-klinopiroksenitovyy kompleks ofiolitov i ego proiskhozhdenie [Dunite-verlite-clinopyroxenite ophiolite complex and its origin], Ekaterinburg, $179 \mathrm{pp}$.

4. Makeev A. B. 1992, Mineralogiya al'pinotipnykh giperbazitov Urala [Mineralogy of alpinotype hyperbasites of the Urals], St. Petersburg, $197 \mathrm{p}$.

5. Perevozchikov B. V. 1995, Zakonomernosti lokalizatsii khromitovogo orudeneniya $v$ al'pinotipnykh giperbazitakh (na primere Urala) [Regularities of the localization of chromite mineralization in alpinotypic hyperbasites (on the example of the Urals)], Moscow, $46 \mathrm{p}$.

6. Pustovetov A. A., Mitina E. A., Ukhanov A. V., Nikol'skaya N. E., Senin V. G. 1992, Neodnorodnost' aktsessornogo khromshpinelida kak vozmozhnyy geotermometr [Heterogeneity of accessory chromospinelide as a possible geothermometer]. Geokhimiya [Geochemistry International], no. 10, pp. 1412-1422.

7. Ukhanov A. V. Nikol'skaya N. E., Guzhova A. V. 1990, Sledy kristallizatsionnoy differentsiatsii $v$ ural'skikh khromitakh [Traces of crystallization differentiation in the Urals chromites]. Geokhimiya [Geochemistry International], no. 1, pp. 61-72.

8. Tsaritsyn E. P. 1983, O vertikal'noy zonal'nosti v giperbazitakh Kempirsayskogo massiva [On the vertical zoning in the hyperbasites of the Kempirsaysky Massif]. Mantiynye ksenolity i problema ul'traosnovnykh magm [Mantle xenoliths and the problem of ultrabasic magmas], Novosibirsk, pp. 186-195.

9. Chashchukhin I. S., Bulykin L. D., Chashchukhina V. A. 2005, O prirode khromitovogo orudeneniya $v$ porodakh dunit-klinopiroksenitovogo kompleksa ofiolitov Srednego Urala [On the nature of chromite mineralization in the rocks of the dunite-clinopyroxenite complex of ophiolites of the Middle Urals]. Ezhegodnik-2004 IGG UrO RAN [Yearbook-2004 IGG RAS], pp. 353-358.

10. Chashchukhin I. S., Votyakov S. L., Shchapova Yu. V. 2007, Kristallokhimiya khromshpineli i oksitermobarometriya ul'tramafitov skladchatykh oblastey [Crystallochemistry of chrome spinels and oximetrybarometry of ultramafites of folded regions], Ekaterinburg, $310 \mathrm{p}$.

11. Yarosh P. Ya. 1980, O pervoistochnike khroma $v$ dunitakh i prirode aktsessornogo khromita [On the primary source of chromium in dunites and the nature of accessory chromite]. Zapiski VMO [Notes of the All-Russian Mineralogical Society], vol. 109, no. 1, pp. 98-105

12. Barnes S. J., Roeder P. L. 2001, The range of spinel compositions in terrestrial mafic and ultramafic rocks. J. Petrol, vol. 42, no. 12, pp. 2279-2302.

\section{Александр Валерьевич Алексеев}

alexeev@igg.uran.ru

Институт геологии и геохимии УрО РАН

им. акад. А.Н. Заварицкого

Россия, Екатеринбург, ул. Куйбышева, 30

\section{Aleksandr Valer'evich Alekseev}

alexeev@igg.uran.ru

Zavaritsky Institute of Geology and Geochemistry

of the Ural Branch of the Russian Academy of Sciences

Ekaterinburg, Russia 